\title{
Emetine, Ipecac, Ipecac Alkaloids and Analogues as Potential Antiviral Agents for Coronaviruses
}

\author{
Martin D. Bleasel and Gregory M. Peterson * $\mathbb{D}$ \\ School of Pharmacy and Pharmacology, University of Tasmania, Hobart Tasmania 7001, Australia; \\ martin.bleasel@gmail.com \\ * Correspondence: g.peterson@utas.edu.au
}

Received: 1 March 2020; Accepted: 20 March 2020; Published: 21 March 2020

\begin{abstract}
The COVID-19 coronavirus is currently spreading around the globe with limited treatment options available. This article presents the rationale for potentially using old drugs (emetine, other ipecac alkaloids or analogues) that have been used to treat amoebiasis in the treatment of COVID-19. Emetine had amongst the lowest reported half-maximal effective concentration $\left(\mathrm{EC}_{50}\right)$ from over 290 agents screened for the Middle East respiratory syndrome (MERS) and severe acute respiratory syndrome (SARS) coronaviruses. While $\mathrm{EC}_{50}$ concentrations of emetine are achievable in the blood, studies show that concentrations of emetine can be almost 300 times higher in the lungs. Furthermore, based on the relative $\mathrm{EC}_{50} \mathrm{~s}$ of emetine towards the coronaviruses compared with Entamoeba histolytica, emetine could be much more effective as an anti-coronavirus agent than it is against amoebiasis. This paper also discusses the known side effects of emetine and related compounds, how those side effects can be managed, and the optimal method of administration for the potential treatment of COVID-19. Given the serious and immediate threat that the COVID-19 coronavirus poses, our long history with emetine and the likely ability of emetine to reach therapeutic concentrations within the lungs, ipecac, emetine, and other analogues should be considered as potential treatment options, especially if in vitro studies confirm viral sensitivity.
\end{abstract}

Keywords: COVID-19; coronavirus; emetine; ipecac; dehydroemetine; MERS; SARS; treatment; repurposing: antiviral

Emetine is one of the main alkaloids found in ipecacuanha (ipecac) root [1]. Ipecac syrup has predominantly been used to induce vomiting in the management of poisoning. Emetine, and perhaps ipecac, ipecac alkaloids and their analogues, should be considered as potentially potent and effective therapeutic agents against the coronavirus family of viruses and, in particular, the COVID-19 coronavirus. As an antiviral, emetine has been shown to have amongst the lowest $\mathrm{EC}_{50}$ value (half-maximal effective concentration) from over 294 agents screened, with an $\mathrm{EC}_{50}$ of 0.054 and $0.014 \mu \mathrm{M}$ for the severe acute respiratory syndrome (SARS) and the Middle East respiratory syndrome (MERS) coronaviruses, respectively [2,3]. Outlined here is the rationale for the potential use of emetine or similar compounds in the treatment of coronavirus infections and, if confirmed from in vitro sensitivity analyses, COVID-19.

Emetine, as an isolated alkaloid, was used as an anti-infective agent from 1912 when Vedder [4] showed that the drug killed amoebae in vitro. It was one of the most widely used agents, orally or intramuscularly, in the treatment of both intestinal and extraintestinal amoebiasis [5-8] until metronidazole became available [5]. Emetine is structurally unrelated to metronidazole.

In a study looking at the amount of emetine absorbed after a $30 \mathrm{~mL}$ oral dose of ipecac (containing $13.9 \mathrm{mg}$ of emetine) in 10 subjects, the mean plasma concentration between 1 and $3 \mathrm{~h}$ post-dosing was approximately $6.5 \mathrm{ng} / \mathrm{mL}(0.0135 \mu \mathrm{M})$, which equates to only 0.25 to $\sim 1$ times the $\mathrm{EC}_{50}$ for SARS and 
MERS coronaviruses, with all patients vomiting at the $30 \mathrm{~mL}$ dose [9]. While the emetic effects of ipecac syrup ( $30 \mathrm{~mL}$ ) can be completely eliminated and nausea significantly reduced by the use of 5-HT3 antagonists, such as ondansetron [10], which may enable higher blood levels to be achieved, these results might initially appear uninspiring. However, as coronaviruses are predominantly respiratory tract infections, the amount of emetine in the lungs is more important than in the plasma. Oral bioavailability studies of ipecac alkaloids in rats have shown that the concentration of radiolabeled emetine is many times higher in the tissues than in plasma. In relation to the lungs, after 8 and $24 \mathrm{~h}$, the concentration of emetine in the lungs is 173 and 294 times higher than in plasma, respectively, with the maximum recorded amount present in the lungs at the 24-h time period. High concentrations were also found in many other tissues, such as the liver, heart, and small and large intestines [11]. Similarly, studies in humans have strongly indicated that emetine quickly undergoes extensive distribution to the tissues [9], with slow excretion and detectable concentrations that may persist in the urine for 40-60 days after treatment has been ceased [12].

It may therefore be possible that the lung concentrations of emetine after the oral administration of ipecac syrup are sufficient for anti-coronavirus activity, especially if other ipecac alkaloids in the syrup also have antiviral properties and it is taken with a 5-HT3 antagonist to avoid vomiting. As an example, cephaeline (another principal alkaloid of ipecac) has been shown to have low nanomolar $\mathrm{IC}_{50}$ (half-maximal inhibitory concentration) values of less than $0.042 \mu \mathrm{M}$ against the Zika virus [13].

Unfortunately, emetine absorption from oral ipecac displays considerable inter-patient variation [14]. Some patients may not absorb sufficient emetine or alkaloids to be therapeutically effective. Intramuscular administration of emetine has a number of advantages over oral dosing. Emetine undergoes metabolism by the liver [15]. Intramuscular administration would prevent any liver metabolism during oral absorption (the "first-pass effect"). Radiolabeled emetine given parenterally, as with oral administration, accumulates in the lung [16]. In fact, another advantage of intramuscular over oral administration could be its greater uptake by the lungs. With radiolabeled emetine given by the oral route in rats, there was, at most time points, significantly (0.8-5.8 times) more emetine found in the liver than there was in the lungs [11]. Conversely, with radiolabeled emetine given by the intraperitoneal route in guinea pigs, the situation was reversed; at each time point, there was over twice as much emetine in the lungs than the liver [16]. It could initially be argued that this reflects interspecies variation. The more likely explanation is that with drugs absorbed into the intestinal circulation following oral administration, the first organ the circulation goes to is the liver, in order that foreign compounds can be detoxified. This results in a higher initial deposition in the liver, with the proportion in the liver decreasing throughout the day as it redistributes into the systemic circulation. With parenteral administration, once a drug enters the circulatory system, the first organ after leaving the heart is the lungs, resulting in higher concentrations to potentially counteract the COVID-19 virus.

Intramuscular administration of emetine can also result in nausea and vomiting [12] which, based on studies with ipecac syrup [10], are likely to be negated with the concomitant use of a 5-HT3 antagonist. It is unlikely that the two agents would be antagonistic to each other with regard to anti-viral activity, especially as emetine has a high affinity for the 5-HT4 receptor with little activity on 5-HT3 [17]. However, it should at least be considered that they could interact until in vitro studies can confirm otherwise.

But how can we be sure that effective concentrations are achieved by the intramuscular route? Emetine, given intramuscularly, has been established over a long period as the most specific and highly potent agent against intestinal and extra-intestinal amoebiasis [18]. The $\mathrm{IC}_{50}$ of emetine against Entamoeba histolytica is $26.8 \mu \mathrm{M}$ [19]; this is approximately $500-1900$ times higher than the $\mathrm{EC}_{50}$ for the SARS and MERS coronaviruses, implying that emetine is potentially far more potent as an anti-coronavirus agent than it is against amoebiasis. These results may cast doubt on the very low $\mathrm{EC}_{50}$ obtained with the SARS and MERS coronaviruses; however, studies by different authors have shown that emetine also has potent antiviral activity against the Zika virus $\left(\mathrm{IC}_{50}=0.00874 \mu \mathrm{M}\right)[13]$ and the human cytomegalovirus $\left(\mathrm{EC}_{50}=0.04 \mu \mathrm{M}\right)$ [20]. Interestingly, emetine also demonstrated 
a dose-dependent inhibition of Ebola virus viral-like particle entry into HeLa cells $\left(\mathrm{IC}_{50}=10.2 \mu \mathrm{M}\right)$ [13]. At $0.03 \mu \mathrm{M}$, emetine was able to reduce HIV (wild type and multi-drug resistant M184V) infection by up to $80 \%$ in peripheral blood mononuclear cells (PBMC) [21]. HIV reverse transcriptase was also reduced by approximately $50 \%$ at an emetine concentration of $10 \mu \mathrm{M}$ [21]. In relation to the coronaviruses, emetine activity against four strains of coronavirus had $\mathrm{EC}_{50}$ values ranging from 0.12 to $1.43 \mu \mathrm{M}$, with the MERS coronavirus $\mathrm{EC}_{50}$ being $0.34 \mu \mathrm{M}$ [22]. While this $\mathrm{EC}_{50}$ for the MERS virus is higher than in previous studies [3], it does indicate that emetine is highly active against multiple coronaviruses. It has also been demonstrated that emetine can reduce viral entry into DPP4-expressing Huh-7.5 cells by a factor of 50-fold compared with that of the control, with an $\mathrm{EC}_{50}$ value of $0.16 \mu \mathrm{M}$ [22].

The main therapeutic issue with emetine use is perhaps its potential for cardiac toxicity. This was especially prevalent in India, where it was estimated that $10 \%-40 \%$ of the population had suffered from amoebiasis, resulting in the use of emetine being "widespread and lavish" [18]. Emetine use was associated with changes in the electrocardiogram (ECG) - in particular, prolongation of the QT interval, elevation of the ST segment and inversion of the T wave [18]. A review in 1980 of the cardiac toxicity found that at therapeutic doses $(1 \mathrm{mg} / \mathrm{kg}$ intramuscularly, maximum $60 \mathrm{mg}$, per day for 10 days or less [5]) non-permanent cardiovascular side effects occurred. This frequently included ECG changes and moderate hypotension [5] and occasionally tachycardia and precordial pain. These changes occurred during treatment or after completion of treatment and often lasted for a period of time. The patient usually recovered without any sustained change in cardiovascular function [5]. Similarly, chronic ingestion of ipecac syrup over many months by sufferers of bulimia nervosa has been associated with cardiac fractional shortening due to cardiomyopathy, but this has been known to revert to normal after the ipecac was ceased [23]. While rare, deaths from ipecac syrup overuse have been reported [24].

Considering the substantially higher potency that emetine appears to have against the coronavirus, doses of one fifth to one tenth of the doses used for the treatment of amoebiasis $(0.1-0.2 \mathrm{mg} / \mathrm{kg}$, intramuscularly; maximum 6-12 mg/day) could potentially be used. These lower doses are likely to minimise or eliminate any significant cardiac toxicity and nausea while maintaining antiviral effectiveness. It should also be noted that the intravenous route was considered too toxic and offered no therapeutic advantages [6], and appropriate pharmaceutical references such as those listed [6,12] should be consulted before clinical use in patients. For the formulation and testing of an emetine injection, both the United States Pharmacopoeia and the British Pharmacopoeia (BP) have listed Emetine Injections [12], with emetine only being omitted from the BP 2013 edition onwards [25], and still available as a reference standard from the US Pharmacopoeia website [26].

If it was used in patients, it is beyond the scope of this article to suggest at which stage in the disease process an agent such as emetine should be used to treat coronavirus infection. Too early and prolific use could promote resistance. If therapy is left too late when acute respiratory distress [27] has developed, it may limit the effectiveness of the drug.

A related compound to emetine that should be tested in vitro for coronavirus sensitivity is dehydroemetine, which was developed in response to the cardiovascular toxicity associated with emetine. Dehydroemetine is structurally similar to emetine but is recognised as having a lower cardiovascular risk profile then emetine [18] and has been used as a replacement for many years. Dehydroemetine is eliminated from tissues more quickly [16], which may explain its lower toxicity. However, at present, there are little sensitivity data for the use of dehydroemetine as an antiviral agent.

Under normal situations, it would be unexpected that an antibacterial compound would also be an antiviral compound. More unlikely, that the same mode of action would account for both antibacterial and antiviral activities. As emetine affects ribosomal protein synthesis in yeast and has been shown to inhibit viral-RNA synthesis [28], there may be some overlap between its antibacterial and antiviral modes of action. If this is the case, the significant structural activity relationships gained from the emetine analogues [28] could be applied to the development of new antiviral agents. 
Emetine was selected from a list of drugs that had been tested in vitro for their antiviral activity against coronaviruses [2]; see Table 1. For each drug, a mid-range achievable blood level was obtained from the literature. This blood level was, in part, arbitrary as blood levels are mostly determined by the dose, which can vary considerably based on the condition being treated; there is also limited availability of studies measuring blood concentrations in patients. The ratio of the blood concentration/ $/ \mathrm{IC}_{50}$ was used to initially rank a drug's potential clinical significance as an antiviral agent against coronaviruses. Drugs that had higher ratios were deemed to be more clinically important, as it signified that therapeutic antiviral concentrations were more likely to be achievable at normal dosing. This system, by itself, proved inadequate, especially in the case of emetine. First, blood levels varied between studies. One study reported the range [14] of levels achieved, while another recorded the mean [9], with the midpoint of the range and the mean being very different. This initially indicated that emetine could be very useful, with a blood concentration/ $/ \mathrm{IC}_{50}$ ratio of approximately 8 (see Table 1 ). When a more realistic blood concentration using the mean was found, the ratio was less than 2. Second, the blood levels do not take into consideration the tissue distribution of the drug. Basic pharmacokinetic parameters of each drug, such as the volume of distribution as an indicator of tissue uptake, should have been used to identify drugs that could potentially exhibit favourable tissue distribution. However, the volume of distribution data alone is not sufficient to determine specific tissue accumulation. A high volume of distribution indicates that the drug is removed from the plasma and goes into the tissues, but which tissues? Lipophilic drugs, with a high volume of distribution, are of little use if the drug partitions solely into adipose tissue. Similarly, a high distribution into the bones, as for bisphosphonates [29], would also be of little use in this scenario. Emetine has good radiolabeled studies [11,16] that clearly showed that not only was the bulk of the emetine distributed in the tissues, but also a significant portion went to the lungs.

Regardless, Table 1 is still able to highlight some drugs that may be of use. This would include agents such as lopinavir, hydroxychloroquine and mycophenolate with or without interferon beta- $1 \mathrm{~b}$. In the case of mycophenolate with interferon beta- $1 b$, it appears to have been therapeutically effective in treating patients with MERS [30]. Given the blood concentration/ $/ \mathrm{IC}_{50}$ ratio of $\sim 30$, calculated on trough levels for mycophenolate with interferon beta- $1 b$, sub-therapeutic immunosuppressive doses may still have antiviral efficacy, especially if used in combination with other drugs such as hydroxychloroquine or lopinavir. From animal studies, interferon beta- $1 \mathrm{~b}$ appears to exhibit antiviral activity against the coronavirus on its own [31].

From Table 2, adapted from Salata 2017 [32], it can be seen that commercially available cationic amphiphilic drugs screened for their antiviral activity often exhibit antiviral activity against different types or families of viruses, with similar $\mathrm{IC}_{50} / \mathrm{EC}_{50}$. It is possible that a number of agents from this list could also be active against the COVID-19 virus.

At present, emetine has advantages which, when considered together, make it an attractive candidate: it significantly inhibits two coronaviruses in the low nano-molar range; it potentially achieves satisfactory plasma levels when administered orally; and it produces substantially higher concentrations in affected tissues (the lungs) that are known to effectively treat Entamoeba histolytica infections, which have inhibitory concentrations hundreds of times higher than at least two coronaviruses. Emetine also has a long and broad history of use, and its side effects are well known and are manageable.

Given the serious and immediate threat that the COVID-19 virus poses, our long if not partially forgotten history with emetine and dehydroemetine, and the likely ability of emetine to reach therapeutic concentrations within the lungs, ipecac, emetine, and other analogues should be considered as potential treatment options, especially if in vitro studies confirm that the COVID-19 virus is sensitive to these agents. 
Table 1. Inhibitory activities of the reported MERS-CoV replication inhibitors available in the FDA-approved drug register (adapted from Liu 2015 [2]) with approximate therapeutic blood concentrations and corresponding ratio of blood concentration and $\mathrm{IC}_{50}$.

\begin{tabular}{|c|c|c|c|c|c|c|}
\hline & $\mathrm{IC}_{50} \mu \mathrm{M}$ (a) & MW g/mole & $\begin{array}{l}\text { Blood [Conc. } \\
\mu \mathrm{M}](\mathrm{b})\end{array}$ & $\begin{array}{c}\text { Ratio: }(\text { Blood [Conc } \\
\mu \mathrm{M}]) / \mathrm{IC}_{50}\end{array}$ & $\begin{array}{c}\text { Blood } \\
\text { [Conc.] Ref. }\end{array}$ & Additional Notes \\
\hline Lopinavir & 17 & 628.81 & 11.45 & 0.67 & [33] & $\mathrm{Cmin} 7.2 \mathrm{mg} / \mathrm{L}, 400 \mathrm{mg}$ twice daily \\
\hline Loperamide & 5.9 & 477 & 0.001 & $<0.005$ & [34] & $\sim 0.5 \mathrm{ng} / \mathrm{mL}$ after $4 \mathrm{mg}$ dose \\
\hline Chloroquine & 5.2 & 319.9 & 1.56 & 0.30 & [35] & $\sim 0.5 \mathrm{mg} / \mathrm{L}$ dose, $450 \mathrm{mg} /$ day \\
\hline \multicolumn{2}{|c|}{ Hydroxychloroquine 8.28} & 335.9 & 3.72 & 0.45 & [36] & $\begin{array}{l}\text { range of } 500-2000 \mathrm{ng} / \mathrm{mL} \text {, dose } \\
\text { maximum of } 200-400 \mathrm{mg} / \text { day } \\
\text { depending on renal function }\end{array}$ \\
\hline Amodiaquine & 6.21 & 355.86 & 0.76 & 0.12 & [37] & $\begin{array}{l}\sim 270 \mathrm{ng} / \mathrm{mL}, 10 \mathrm{mg} / \mathrm{kg} \text { single dose; Is } \\
\text { rapidly metabolised to } \\
\text { desethylamodiaquine - blood level is } \\
\text { for metabolite (assumed to be as } \\
\text { active as parent) }\end{array}$ \\
\hline Chlorpromazine & 9.15 & 318.86 & 0.52 & 0.06 & [38] & $\begin{array}{l}\text { Reference range: } 30-300 \mathrm{ng} / \mathrm{mL} \\
\text { Large volume of distribution [38] }\end{array}$ \\
\hline Promethazine & 11.8 & 284.4 & 0.02 & $<0.005$ & [39] & $\begin{array}{c}\sim 5 \mathrm{ng} / \mathrm{mL} \text { peak, } 25 \mathrm{mg} \text { oral single } \\
\text { dose } \\
\text { Large volume of distribution [39] }\end{array}$ \\
\hline Fluphenazine & 5.86 & 437.52 & 0.01 & $<0.005$ & [38] & $\begin{array}{l}\text { Reference range: } 1-10 \mathrm{ng} / \mathrm{mL} \\
\text { Large volume of distribution [38] }\end{array}$ \\
\hline Thiothixene & 9.3 & 443.6 & 0.05 & $<0.005$ & [40] & 3-45 ng/mL, $20 \mathrm{mg}$ dose \\
\hline Astemizole & 4.88 & 458.57 & 0.17 & 0.04 & [41] & $\begin{array}{c}\sim 70 \mu \mathrm{g} / \mathrm{L} \text { peak, } 300 \mathrm{mg} \text { single oral } \\
\text { dose. Blood level was astemizole + } \\
\text { hydroxylated (active) metabolites. } \\
\text { Large volume of distribution. }\end{array}$ \\
\hline Triflupromazine & 5.76 & 352.418 & & & & Insufficient data to make assessment \\
\hline Clomipramine & 9.33 & 314.9 & 1.05 & 0.11 & [38] & $\begin{array}{l}\text { Reference range: } 230-450 \mathrm{ng} / \mathrm{mL} \\
\text { Large volume of distribution [38] }\end{array}$ \\
\hline Emetine & 0.01 & 480.64 & 0.08 & 8.32 & [14] & $\begin{array}{l}5 \text { to } 73 \mathrm{ng} / \mathrm{mL}, 11.4 \mathrm{mg} \text { oral dose. The } \\
\text { blood concentration used was the } \\
\text { midpoint in subjects with detectable } \\
\text { levels of emetine }\end{array}$ \\
\hline Tamoxifen & 10.12 & 371.5 & 0.32 & 0.03 & [42] & $120 \mathrm{ng} / \mathrm{mL}, 20 \mathrm{mg}$ daily \\
\hline Cycloheximide & 0.19 & & & & & Too toxic [43] \\
\hline Dasatinib & 5.47 & 488.01 & 0.003 & $<0.005$ & [44] & $\mathrm{Cmin}$ to $<3 \mathrm{nmol} / 1$ \\
\hline Ribavirin (c) & 40.9 & 244.2 & 8.19 & 0.20 & [45] & $\begin{array}{c}<30 \% \text { of patients obtained this } \\
\text { concentration } 2 \mathrm{mg} / \mathrm{l} \text { after } 24 \text { weeks } \\
{[45]}\end{array}$ \\
\hline $\begin{array}{l}\text { Mycophenolic } \\
\text { acid (c) (d) }\end{array}$ & 0.53 & 320.34 & 6.24 & 11.78 & [46] & $\begin{array}{l}\text { The blood concentrations are the } \\
\text { troughs; the peaks are substantially } \\
\text { higher. Calculated on a trough of } \\
\qquad 2 \mu \mathrm{g} / \mathrm{mL}\end{array}$ \\
\hline $\begin{array}{l}\text { Mycophenolic } \\
\text { acid }+12.5 \\
\mathrm{IU} / \mathrm{mL} \\
\text { interferon } \\
\text { beta- } 1 \mathrm{~b}(\mathrm{~d}) \\
\text { (e) }\end{array}$ & 0.187 & 320.34 & 6.24 & 33.39 & {$[46,47]$} & $\begin{array}{l}\text { The blood concentrations are the } \\
\text { troughs; the peaks are substantially } \\
\text { higher. Calculated on a trough of } \\
\qquad 2 \mu \mathrm{g} / \mathrm{mL}\end{array}$ \\
\hline
\end{tabular}

Notes: Data from Liu 2015 [2] unless otherwise stated. (b) Blood levels cannot be exact and will vary depending on dose, condition being treated and available studies. (c) Value calculated from Chan 2013 [48] (d) Mycophenolic acid is the active metabolite of mycophenolate. Mycophenolate with interferon beta- $1 \mathrm{~b}$ appears to have been therapeutically effective in treating patients with MERS [30]. 
Table 2. Antiviral efficacy of selected cationic amphiphilic drugs, adapted from Salata 2017 [32].

\begin{tabular}{|c|c|}
\hline Drug & Antiviral Efficacy \\
\hline Amiodarone & $\begin{array}{c}\text { Filovirus- } \mathrm{IC}_{50} 0.25-1.38 \mu \mathrm{g} / \mathrm{mL} \\
\text { Ebola virus- } \mathrm{IC}_{50} 5.60 \mu \mathrm{M} \\
\mathrm{HCV}-\mathrm{EC}_{50} 2.10 \mu \mathrm{M}\end{array}$ \\
\hline Bepridil & Ebola virus- $-\mathrm{IC}_{50} 3.21-5.08 \mu \mathrm{M}$ \\
\hline $\begin{array}{l}\text { Chloroquine } \\
\text { and } \\
\text { Hydroxychloroquine }\end{array}$ & 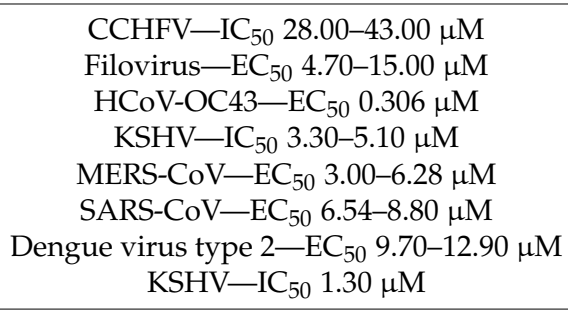 \\
\hline Quinacrine & $\begin{array}{c}\text { Dengue virus type } 2-\mathrm{EC}_{50} 7.09 \mu \mathrm{M} \\
\text { Zika virus-EC } \mathrm{E}_{50} 2.27 \mu \mathrm{M}\end{array}$ \\
\hline Mefloquine & $\begin{array}{c}\text { Dengue virus type } 2-\mathrm{EC}_{50} 4.36 \mu \mathrm{M} \\
\text { Zika virus-EC } \mathrm{C}_{50} 3.95 \mu \mathrm{M}\end{array}$ \\
\hline Chlorpromazine & $\begin{array}{c}\text { CCHFV-IC } \mathrm{IC}_{50} 10.80-15.70 \mu \mathrm{M} \\
\text { MERS-CoV-EC }{ }_{50} 4.90-9.51 \mu \mathrm{M} \\
\text { SARS-CoV-EC } \\
50\end{array}$ \\
\hline Promethazine & Filovirus- $-\mathrm{IC}_{50} 19.10-19.40 \mu \mathrm{M}$ \\
\hline Sertraline & Ebola virus $-\mathrm{IC}_{50} 1.44-3.13 \mu \mathrm{M}$ \\
\hline Trimipramine & Filovirus- $-\mathrm{IC}_{50} 10.90-11.10 \mu \mathrm{M}$ \\
\hline Clomiphene & $\begin{array}{c}\text { Filovirus- } \mathrm{IC}_{50} 0.76-11.10 \mu \mathrm{M} \\
\mathrm{HCV}-\mathrm{EC}_{50}\end{array}$ \\
\hline Tamoxifen & $\begin{array}{c}\text { HCV-EC } 50.10 \mu \mathrm{M} \\
\text { HSV-IC } 504.89 \mu \mathrm{M} \\
\text { MERS-CoV-EC } 5010.12 \mu \mathrm{M} \\
\text { SARS-CoV-EC } 5092.89 \mu \mathrm{M}\end{array}$ \\
\hline Toremifene & $\begin{array}{l}\text { Filovirus- }-\mathrm{IC}_{50} 0.03-6.17 \mu \mathrm{M} \\
\text { MERS-CoV-EC } 5012.92 \mu \mathrm{M} \\
\text { SARS-CoV-EC } 5011.97 \mu \mathrm{M}\end{array}$ \\
\hline Sunitinib & $\mathrm{HCV}-\mathrm{IC}_{50} 0.05 \mu \mathrm{M}$ \\
\hline Terconazole & Ebola virus- $-\mathrm{IC}_{50} 7.07-8.26 \mu \mathrm{M}$ \\
\hline Triparanol & Ebola virus- $\mathrm{IC}_{50} 1.92 \mu \mathrm{M}$ \\
\hline
\end{tabular}

Author Contributions: Conceptualization, M.D.B.; methodology, M.D.B.; validation, M.D.B. and G.M.P.; writing—original draft preparation, M.D.B. and G.M.P.; writing—review and editing, M.D.B. and G.M.P. All authors have read and agreed to the published version of the manuscript.

Funding: This research received no external funding.

Conflicts of Interest: The authors declare no conflict of interest.

\section{References}

1. Lee, M.R. Ipecacuanha: The South American vomiting root. J. R. Coll. Physicians Edinb. 2008, 38, 6.

2. Liu, Q.; Xia, S.; Sun, Z.; Wang, Q.; Du, L.; Lu, L.; Jiang, S. Testing of Middle East Respiratory Syndrome coronavirus replication inhibitors for the ability to block viral entry. Antimicrob. Agents Chemother. 2014, 59, 742-744. [CrossRef] [PubMed]

3. Dyall, J.; Coleman, C.; Hart, B.; Venkataraman, T.; Holbrook, M.R.; Kindrachuk, J.; Johnson, R.F.; Olinger, G.; Jahrling, P.B.; Laidlaw, M.; et al. Repurposing of clinically developed drugs for treatment of Middle East Respiratory Syndrome coronavirus infection. Antimicrob. Agents Chemother. 2014, 58, 4885-4893. [CrossRef] [PubMed] 
4. Vedder, E.B. An experimental study of the action of ipecacuanha on amoebae. Far East. Assoc. Trop. Med. Trans. Second Bienn. Congr. Held Hongkong 1912, 87-91.

5. Yang, W.C.; Dubick, M. Mechanism of emetine cardiotoxicity. Pharmacol. Ther. 1980, 10, 15-26. [CrossRef]

6. Gilman, A.; Goodman, L.; Goodman, A. (Eds.) Pharmacological Basis Therapeutics, 6th ed.; Macmillan: New York, NY, USA, 1980; ISBN 978-0-02-344720-4.

7. Scragg, J.N.; Powell, S.J. Emetine hydrochloride and chloroquine in the treatment of children with amoebic liver abscess. Arch. Dis. Child. 1966, 41, 549-550. [CrossRef]

8. Foy, G. Ipecacuanha and emetine. Lancet 1912, 180, 1242. [CrossRef]

9. Scharman, E.J.; Hutzler, J.M.; Rosencrance, J.G.; Tracy, T.S. Single dose pharmacokinetics of syrup of ipecac. Ther. Drug Monit. 2000, 22, 566-573. [CrossRef]

10. Minton, N.; Swift, R.; Lawlor, C.; Mant, T.; Henry, J. Ipecacuanha-induced emesis: A human model for testing antiemetic drug activity. Clin. Pharmacol. Ther. 1993, 54, 53-57. [CrossRef]

11. Asano, T.; Ishihara, K.; Wakui, Y.; Yanagisawa, T.; Kimura, M.; Kamei, H.; Yoshida, T.; Kuroiwa, Y.; Fujii, Y.; Yamashita, M.; et al. Absorption, distribution and excretion of $3 \mathrm{H}-$ labeled cephaeline- and emetine-spiked ipecac syrup in rats. Eur. J. Drug Metab. Pharmacokinet. 2002, 27, 17-27. [CrossRef]

12. Reynolds, J.E.F.; Parfitt, K.; Parsons, A.; Sweerman, S. (Eds.) Martindale: The Extra Pharmacopoeia, 29th ed.; The Pharmaceutical Press: London, UK, 1989; ISBN 978-0-85369-210-2.

13. Yang, S.; Xu, M.; Lee, E.M.; Gorshkov, K.; Shiryaev, S.A.; He, S.; Sun, W.; Cheng, Y.-S.; Hu, X.; Tharappel, A.M.; et al. Emetine inhibits Zika and Ebola virus infections through two molecular mechanisms: Inhibiting viral replication and decreasing viral entry. Cell Discov. 2018, 4, 31. [CrossRef] [PubMed]

14. Moran, D.M.; Crouch, D.J.; Finkle, B.S. Absorption of ipecac alkaloids in emergency patients. Ann. Emerg. Med. 1984, 13, 1100-1102. [CrossRef]

15. Asano, T.; Watanabe, J.; Sadakane, C.; Ishihara, K.; Hirakura, K.; Wakui, Y.; Yanagisawa, T.; Kimura, M.; Kamei, H.; Yoshida, T.; et al. Biotransformation of the ipecac alkaloids cephaeline and emetine from ipecac syrup in rats. Eur. J. Drug Metab. Pharmacokinet. 2002, 27, 29-35. [CrossRef] [PubMed]

16. Schwartz, D.E.; Herrero, J. Comparative pharmacokinetic studies of dehydroemetine and emetine in guinea pigs using spectrofluorometric and radiometric methods. Am. J. Trop. Med. Hyg. 1965, 14, 78-83. [CrossRef]

17. Hasegawa, M.; Sasaki, T.; Sadakane, K.; Tabuchi, M.; Takeda, Y.; Kimura, M.; Fujii, Y. Studies for the emetic mechanisms of ipecac syrup (TJN-119) and its active components in ferrets: Involvement of 5-hydroxytryptamine receptors. Jpn. J. Pharmacol. 2002, 89, 113-119. [CrossRef]

18. Stephen, P.M. Chapter 9: Cardiotoxicity of emetine and analogs. In Principles of Cardiac Toxicology; CRC Press: Boca Raton, FL, USA, 1991; ISBN 978-1-4398-0536-7.

19. Bansal, D.; Sehgal, R.; Chawla, Y.; Mahajan, R.C.; Malla, N. In vitro activity of antiamoebic drugs against clinical isolates of Entamoeba histolytica and Entamoeba dispar. Ann. Clin. Microbiol. Antimicrob. 2004, 3, 27. [CrossRef]

20. Mukhopadhyay, R.; Roy, S.; Venkatadri, R.; Su, Y.-P.; Ye, W.; Barnaeva, E.; Griner, L.M.; Southall, N.; Hu, X.; Wang, A.Q.; et al. Efficacy and mechanism of action of low dose emetine against human cytomegalovirus. PLOS Pathog. 2016, 12, e1005717. [CrossRef]

21. Valadão, A.L.C.; Abreu, C.M.; Dias, J.Z.; Arantes, P.R.; Verli, H.; Tanuri, A.; Aguiar, R. Natural plant alkaloid (emetine) inhibits HIV-1 replication by interfering with reverse transcriptase activity. Molecules 2015, 20, 11474-11489. [CrossRef]

22. Shen, L.; Niu, J.; Wang, C.; Huang, B.; Wang, W.; Zhu, N.; Deng, Y.; Wang, H.; Ye, F.; Cen, S.; et al. High-throughput screening and identification of potent broad-spectrum inhibitors of coronaviruses. J. Virol. 2019, 93. [CrossRef]

23. Ho, P.C.; Dweik, R.; Cohen, M.C. Rapidly reversible cardiomyopathy associated with chronic ipecac ingestion. Clin. Cardiol. 1998, 21, 780-783. [CrossRef]

24. Adler, A.G.; Walinsky, P.; Krall, R.A.; Cho, S.Y. Death resulting from ipecac syrup poisoning. JAMA 1980, 243, $1927-1928$. [CrossRef] [PubMed]

25. British Pharmacopoeia Omitted-monographs-BP-2000-to-2013-Updated.pdf. Available online: https://www.pharmacopoeia.com/file/monograph\%20information/Omitted-monographs-BP-2000-to-2013--updated.pdf (accessed on 21 March 2020).

26. USP Reference Standard: Emetine Hydrochloride (300 mg). Available online: https://store.usp.org/OA_ HTML/ibeCCtpItmDspRte.jsp?item=18786 (accessed on 25 February 2020). 
27. WHO. Clinical Management of Severe Acute Respiratory Infection When Novel Coronavirus (2019-nCoV) Infection is Suspected: Interim Guidance 28 January 2020; World Health Organization: Geneva, Switzerland, 2020; Available online: https://www.who.int/publications-detail/clinical-management-of-severe-acute-respiratoryinfection-when-novel-coronavirus-(ncov)-infection-is-suspected (accessed on 21 March 2020).

28. Akinboye, E.S. Biological activities of emetine. Open Nat. Prod. J. 2011, 4, 8-15. [CrossRef]

29. Allen, M.R. Skeletal accumulation of bisphosphonates: Implications for osteoporosis treatment. Expert Opin. Drug Metab. Toxicol. 2008, 4, 1371-1378. [CrossRef] [PubMed]

30. Al Ghamdi, M.; Alghamdi, K.M.; Ghandoora, Y.; Alzahrani, A.; Salah, F.; Alsulami, A.; Bawayan, M.F.; Vaidya, D.; Perl, T.M.; Sood, G. Treatment outcomes for patients with Middle Eastern Respiratory Syndrome Coronavirus (MERS CoV) infection at a coronavirus referral center in the Kingdom of Saudi Arabia. BMC Infect. Dis. 2016, 16, 174. [CrossRef]

31. Chan, J.F.-W.; Yao, Y.; Yeung, M.L.; Deng, W.; Bao, L.; Jia, L.; Li, F.; Xiao, C.; Gao, H.; Yu, P.; et al. Treatment with lopinavir/ritonavir or interferon- $\beta 1 \mathrm{~b}$ improves outcome of MERS-CoV infection in a nonhuman primate model of common marmoset. J. Infect. Dis. 2015, 212, 1904-1913. [CrossRef]

32. Salata, C.; Calistri, A.; Parolin, C.; Baritussio, A.; Palù, G. Antiviral activity of cationic amphiphilic drugs. Expert Rev. Anti-infective Ther. 2017, 15, 483-492. [CrossRef]

33. Van Der Lugt, J.; Lange, J.M.A.; Avihingsanon, A.; Andrade, B.B.; Sealoo, S.; Burger, D.; Gorowara, M.; Phanuphak, P.; Ruxrungtham, K. Plasma concentrations of generic lopinavir/ritonavir in HIV type-1-infected individuals. Antivir. Ther. 2009, 14, 1001-1004. [CrossRef]

34. Kamali, F; Huang, M.L. Increased systemic availability of loperamide after oral administration of loperamide and loperamide oxide with cotrimoxazole. Br. J. Clin. Pharmacol. 1996, 41, 125-128. [CrossRef]

35. Karunajeewa, H.A.; Salman, S.; Mueller, I.; Baiwog, F.; Gomorrai, S.; Law, I.; Page-Sharp, M.; Rogerson, S.J.; Siba, P.; Ilett, K.F.; et al. Pharmacokinetics of chloroquine and monodesethylchloroquine in pregnancy. Antimicrob. Agents Chemother. 2010, 54, 1186-1192. [CrossRef]

36. Durcan, L.; Clarke, W.; Magder, L.; Petri, M. OP0187 Hydroxychloroquine blood levels in SLE: Clarifying dosing controversies and improving adherence. Ann. Rheum. Dis. 2015, 74, 142-143. [CrossRef]

37. Orrell, C.; Little, F.; Smith, P.; Folb, P.; Taylor, W.; Olliaro, P.; Barnes, K.I. Pharmacokinetics and tolerability of artesunate and amodiaquine alone and in combination in healthy volunteers. Eur. J. Clin. Pharmacol. 2008, 64, 683-690. [CrossRef]

38. Hiemke, C.; Baumann, P.; Bergemann, N.; Conca, A.; Dietmaier, O.; Egberts, K.; Frič, M.; Gerlach, M.; Greiner, C.; Grunder, G.; et al. AGNP Consensus Guidelines for Therapeutic Drug Monitoring in Psychiatry: Update 2011. Pharmacopsychiatry 2011, 44, 195-235. [CrossRef]

39. Taylor, G.; Houston, J.; Shaffer, J.; Mawer, G. Pharmacokinetics of promethazine and its sulphoxide metabolite after intravenous and oral administration to man. Br. J. Clin. Pharmacol. 1983, 15, 287-293. [CrossRef]

40. Yesavage, J.A.; Holman, C.A.; Cohn, R. Correlation of thiothixene serum levels and age. Psychopharmacology 1981, 74, 170-172. [CrossRef]

41. Simons, F.E.; Simons, K.J.; Chung, M.; Yeh, J. The comparative pharmacokinetics of H1-receptor antagonists. Ann. Allergy 1987, 59, 20-24.

42. Zeneca Pharmaceuticals. Professional Information Brochure: Nolvadex (Tamoxifen Citrate); London, UK, 1998. Available online: https://www.accessdata.fda.gov/drugsatfda_docs/label/1998/17970.pdf (accessed on 21 March 2020).

43. Clemedson, C. ACuteTox: 7-Cycloheximide Revised. Available online: http://www.acutetox.eu/pdf_human_ short/7-Cycloheximide\%20revised.pdf (accessed on 21 March 2020).

44. Talpaz, M.T.; Saglio, G.; Atallah, E.; Rousselot, P. Dasatinib dose management for the treatment of chronic myeloid leukemia. Cancer 2018, 124, 1660-1672. [CrossRef]

45. Pedersen, C.; Alsiö, Å.; Lagging, M.; Langeland, N.; Färkkilä, M.; Buhl, M.R.; Mørch, K.; Westin, J.; Sangfelt, P.; Norkrans, G.; et al. Ribavirin plasma concentration is a predictor of sustained virological response in patients treated for chronic hepatitis C virus genotype 2/3 infection. J. Viral Hepat. 2011, 18, 245-251. [CrossRef]

46. Kaplan, B. Mycophenolic acid trough level monitoring in solid organ transplant recipients treated with mycophenolate mofetil: Association with clinical outcome. Curr. Med Res. Opin. 2006, 22, 2355-2364. [CrossRef] 
47. Bayer HealthCare Pharmaceuticals. Betaseron: Highlights of Prescribing Information; Berlin, Germany, 2015. Available online: https://www.accessdata.fda.gov/drugsatfda_docs/label/2018/103471s5193lbl.pdf (accessed on 21 March 2020).

48. Chan, J.F.-W.; Chan, K.-H.; Kao, R.Y.; To, K.K.-W.; Zheng, B.J.; Li, C.P.; Li, P.T.; Dai, J.; Mok, F.K.; Chen, H.; et al. Broad-spectrum antivirals for the emerging Middle East respiratory syndrome coronavirus. J. Infect. 2013, 67, 606-616. [CrossRef]

(C) 2020 by the authors. Licensee MDPI, Basel, Switzerland. This article is an open access article distributed under the terms and conditions of the Creative Commons Attribution (CC BY) license (http://creativecommons.org/licenses/by/4.0/). 